\title{
Accounting
}

\section{The effect of tax rate on sales tax compliance among Jordanian public shareholding corporations}

\author{
Ahmad Farhan Alshira'ha", Ali Mustafa Magabliha and Moh'd Alsqour ${ }^{a}$
}

${ }^{a}$ Accounting Department, Faculty of Administrative and Financial Sciences, Irbid National University, Irbid, 2600, Jordan

\begin{tabular}{l}
\hline C H R O N I C L E \\
\hline Article history: \\
Received: November 28, 2020 \\
Received in revised format: \\
December 282020 \\
Accepted: January 25, 2021 \\
Available online: \\
January 25, 2021 \\
\hline Keywords: \\
Sales Tax Compliance \\
Tax Rate \\
Jordanian Corporations
\end{tabular}

\section{Introduction}

One of the main elements in national income management in both developing and developed nations is taxes (Alshir'ah et al., 2016). Specifically, developing nations are inclined towards the use of money on education, public infrastructure, health services and other public services and as such, they require tax revenue increases as a proportion of GDP in the quest towards growth and development (Bird \& Martinez-Vazquez, 2008). In fact, most countries around the globe depend on (direct and indirect) tax sources for their development (Palil, 2005). Suffice it to say that taxes and the tax system form a crucial element in building and developing nations, particularly developing nations and transitional economies (McKerchar \& Evans, 2009). Taxes are deemed to be a basic pillar of social, political and economic development (Marandu et al., 2015), making collection of tax revenues a top significant issue. This is especially true following the 2008 economic crisis, which led to increased public fiscal deficits of states, raising the need for tax revenues, and urging the states to turn towards universal collaboration to resolve non-compliance of taxes (Sawyer, 2014). More importantly, sales tax non-compliance is among the topic of distinct concern when it comes to taxes in current decades, in such a way that it has transformed sales taxes forms in many countries and remains attractive as a significant topic (Alshira'h \& Abdul-Jabbar, 2019a; Das-Gupta \& Gang, 2003). Sales tax or as referred to by the majority of

* Corresponding author

E-mail address: alshraah.ahmad@yahoo.com (A. F. Alshira'h)

(C) 2021 by the authors; licensee Growing Science, Canada doi: $10.5267 /$ j.ac.2021.1.020 
nations, value added tax (VAT) (in Britain, France, U.S. and Malaysia) was originally brought forward in France in 1954 as a consumption tax on goods and was imposed on the level of production (Adams \& Webley, 2001). Sales tax is viewed to be invaluable in the provision of tax revenues for governments, specifically in the developing nations (Faridy et al., 2016). In the Jordanian context, the shadow economy experienced an increase from 19.4\% (1999) to 20.4\% (2000) of GDP, as a result of which increased sales tax rate was promoted from 10\% -13\% in 1999 (Alkhdour, 2011). The shadow economy also experienced an increase from 2010 to 2015, from 22.1\% to 24.5\% of GDP, according to the Jordanian Economic Social Council (2014). In the developing nations shadow economy, corporations are the top income contributors (Alshir'ah et al., 2018; Arachi \& Santoro, 2007), with tax non-compliance of sole proprietors of such establishments shaping the greater proportion of the total tax non compliance in the U.S. (Birškytė, 2014; Alshira'h et al., 2020). Additionally, Alshira'h and Abdul-Jabbar (2020) and the International Tax Dialogue (2007) revealed that business taxation has attracted heightened interest for the last ten years in both country types (developing and developed). According to Shamsudin (2012), to ensure tax revenues fairness, the whole firm with the inclusion of SMEs should adhere to the tax laws. Similarly, Swistak (2015) highlighted the need for businesses to comply towards tax laws to overcome the issues of their non-compliance. Based on the above discussion, one of the primary strategies through which government policy can be reinforced is through the enhanced compliance towards tax and mitigation of tax noncompliance. Government effort concerning tax compliance encapsulates enhancing extensive vision and plans for the next decade in Jordan to adopt the fundamental principle of fiscal sustainability by 2025 via self-reliance and competitiveness. This is expected to assist the promotion of Jordan's impervious national economy, and in so doing, the country will be able to mitigate the external shocks' effects on the performance of its economy. Hence, tax non-compliance in Jordan is an important issue that underlines the need for Jordanian tax payers tax compliance. Sales tax non-compliance needs precise examination of the behavioral and economic factors that influence sales tax compliance in Jordan to differentiate the issue's origin and to resolve it, particularly in the face of economic challenges.

\section{Literature Review and Hypotheses Development}

\subsection{Tax Compliance}

Taxes constitute significant elements of the country's total domestic revenue, whether developing or developed and throughout the world, countries economic promotion is highly dependent on direct and indirect taxes (Alshira'h \& Abdul-Jabbar, 2019b; Tehulu \& Dinberu, 2014; Gundarapu \& Vadde, 2012; Torgler \& Schaltegger, 2005). Every single person, whether corporate or individual has a duty to pay taxes and is expected to have the voluntary willingness to adhere to tax law, but some individuals still steer clear of tax payment (Seidu, Abdul \& Sebil, 2015; Kirchler, Kogler \& Muehlbacher, 2014; Junpath, 2013). So noncompliance firms and individuals towards tax payment form a challenge to the tax agencies in every country (Jayawardane, 2015).

Tax compliance generation and guarantee hinges on the government's efforts towards urging taxpayers' participation in governmental decisions and expenditures (Alshira'h, Al-ShatnawiAl-Okaily, Alshirah et al., 2020; Alm, Jackson \& Mc Kee, 1993), and on the increased tax audit as well as penalties (Alm \& Torgler, 2011). Regardless of the numerous efforts of the governments to tackle tax non-compliance, the issue remains ongoing and rife with complexity (Ali, 2013). In fact, tax compliance is deemed to be one of the top current issues, specifically in the developing nations that are in constant search for efficiency development when it comes to tax revenue collection to support government budgets.

In relation to the above, Devos (2005) contended that a specific standard for tax compliance definition has yet to be proposed throughout literature. Generally speaking, tax compliance refers to the ability and inclination of the taxpayer to adhere to the tax laws, depending on the ethics, legal environment and other situational factors at a specific time and place (Gundarapu \& Vadde, 2012; Palil \& Mustapha, 2011; Kirchler, Niemirowski \& Wearing, 2006). Kirchler, Niemirowski and Wearing (2006) described tax compliance as a game that hinges on the reciprocal interactions between the taxpayer's decisions and the tax agency, and as the taxpayer's trust in tax law and the just tax system. From the above, it is evident that there are multiple measures to tax compliance in an attempt to determine taxpayers' compliance and they are of three types; reporting compliance, filing compliance and payment compliance (Brown \& Mazur, 2003).

Throughout literature, tax compliance has been used synonymous with tax avoidance, tax evasion, and tax fraud, with researchers distinguishing between tax evasion and tax avoidance (Alshira'h, 2018; O'Shaughnessy, 2014). While tax noncompliance takes the form of tax evasion/tax avoidance, depending on the legality degree of the illegal business or legal business of the taxpayer (Likhovski, 2007), tax evasion entails illegal and intended businesses by institutions and individuals to decrease their duet legal tax commitment, through the under-reporting of sales, income or wealth, or the exaggeration of deductions, dispensations, or loans, or through the filing of erroneous tax returns (Ritsatos, 2014). Another take on the definition of tax evasion came from Kasipillai, Aripin and Amran (2003), who referred to it as a premeditated action of tax non-compliance to producing payment of lower tax compared to what is actually owed. Meanwhile, Abdul-Jabbar and Pope (2008) revealed that tax evasion covers illegal behavior elements combined with intention of the taxpayer to mislead intentionally while reporting 
tax and to deceive the tax authority in order to pay lower tax than what is actually owed. Tax non-compliance may take on various measures and contain failure to submit a tax return at a specific time or non-submission, income understatement, deductions overstatement, and failure to pay assessed taxes by the specified period (Kasipillai \& Jabbar, 2006).

In comparison, tax avoidance is said to occur when ambiguities/impairment in the tax law are leveraged to decrease duty tax and breaking liabilities, and it may be referred to as having an unethical element to it (Bruce-Twum, 2014). While tax avoidance is legal, indicating the clever manipulation of the taxpayers of their affairs so as to lower their tax payment (Alshir'ah, AbdulJabbar \& Samsudin, 2019; Kasipillai et al., 2003). Moreover, Likhovski (2007) referred to tax avoidance an act that have a basis on the tax law loopholes and similarly, other authors (e.g., Alshira'h, 2019; Slemrod, 2004; Slemrod \& Yitzhaki, 2002; Alm, Bhai \& Murray, 1990) referred to tax avoidance as a legitimate action towards decreasing taxes.

However, when taxpayers adhere with the owed tax, this lowers the tax gap and tax gap is the monetary variance between collected and due taxes (Mascagni, Moore \& Mccluskey, 2014; Strader \& Fogliasso, 1989). In instances where many individuals decide to evade their tax payment, the state will be hard up in supplying and providing public services (i.e., education, electricity, security, road construction, and health services) at affordable prices. Therefore, policy makers are concerned with noncompliance as it reflects lower revenue and leads to serious government losses. It may also lead to unfair burden for those who pay their taxes, leading to disrespecting the tax system. Hence, tax authorities focus on resolving non-compliance and determining potential measures towards compliance enhancement (Isa, 2012).

\subsection{Taxpayers' Behavior}

Tax payment among taxpayers can be based on many reasons, one of them being that they are inclined towards adhering to specific principles (Torgler, 2003b). Taxpayers can be categorized into three types (Kelman, 1965 cited by Vogel, 1974) in the hopes of realizing a deeper understanding of the reasons behind the motivations behind compliance behavior and means which affect such behavior, and they are; compliance (taxpayers compliance towards tax payment when threatened by tax system punishment), identification (taxpayers compliance towards tax payment when they accept influence from individual/group via social norms), and internalization (taxpayers compliance towards tax payment when it is consistent with their beliefs).

Mirroring Vogel's (1974) typology, various types of taxpayers behavior was also developed by Torgler (2003a) and they are; 1) social taxpayers, which means compliance to tax payment stem from the feeling of shame and guilt when caught in the act of non-compliance - and this is primarily driven by social norms, 2) intrinsic taxpayer, which means compliance to tax payment without force because of the sensitivity to institutional factors like tax agency/government behavior with tax law, extrinsic motivations like oversight and sanctions for those breaching compliance, 3) honest taxpayer, which means people do not search ways to evade tax as they are always ready to pay tax owed, in a behavior that does not change with the change in the tax system policy and 4) tax evader, which means those with lower tax morale and ethics compare between the values of honesty and the tax evasion value. In sum, tax compliance is full of complexity and there is a lack of universal consensus as to its definition. Various theoretical models have been brought forward for compliance behavior, proposing several factors that influence such behavior, necessitating their examination.

\subsection{Tax Rate}

According to the deterrence theory (Allingham \& Sandmo, 1972), tax rate is significantly related with tax compliance and it is deemed to be one of the major factors in the tax system structure, and essentially one of the determinant factors of tax compliance (Richardson, 2006). According to Chau and Leung (2009), tax rate is among the primary tax system constructs mentioned in the Fisher model. It is one of the prime bases that tax revenue relies on, although the increase in gross tax revenue from tax rate growth does not only depend on the latter's magnitude but also on the taxpayers' response to such growth (Dahlby \& Ferede, 2012). The deterrence theory argues that there is a negative relationship between tax rate and tax compliance (Allingham \& Sandmo, 1972). The theory is supported by majority of the studies in literature including Inasius (2015), Hauptman et al. (2014), Kuehn (2014), Mukhlis, Utomo and Soesetyo (2014), Pellizzari and Rizzi (2014), Barbuta-Misu (2011), Ali, Cecil and Knoblett (2001) and Alm and Mc Kee (1998). In contrast to the above studies, other studies revealed no significant relationship between tax rate and tax compliance (e.g., Modugu, Eragbhe \& Izedonmi, 2012; Richardson, 2006), while others reported a positive relationship between the two (Weber, Fooken \& Herrmann, 2014; Alm, Sanchez \& Juan, 1995). In the Jordanian context, researchers found increased tax rate to be positively related to increased income tax evasion.

From the above discussion, it is evident that tax rate is related to tax compliance although findings from literature are still inconsistent. Majority of such studies focused on income tax, leaving sales tax compliance lagging behind. Added to this, studies examined the relationship between tax rate and tax compliance at the level of the individual and not at the level of business, a context that is lacking in literature. This calls for the need for more studies to focus on examining the tax rate-sales tax compliance relationship due to the former's main influence on tax compliance behavior. To date, no study has been conducted to examine the relationship between the two in the Middle East and Arab countries, also necessitating carrying out such studies, 
particularly the Jordanian context. Thus, based on the above discussion and the argument of the deterrence theory, this study proposes that;

\section{$\mathrm{H}_{1}$ : There is a negative relationship between tax rate and sales tax compliance.}

\section{Measurement}

The definition of sales tax rate adopted by this study is the percentage imposed on supplies of goods and services, whether imported from abroad or from free zones and local producers, if such supply is not sales tax law-exempted. Three items were adopted from Christensen, Weihrich and Newman-Gerbing (1994) to measure sales tax rate in the companies with a few tweaks to suit the objective of the study. Under this subsection the respondents' perceptions of the items are assessed using a 5-point Likert scale with 1 depicting 'strongly disagree' and 5 depicting 'strongly agree'. Specifically, strongly disagree shows that tax rate is unfair, while strongly agrees shows that tax rate is fair. The items used to measure tax rate are listed in Table 1.

\section{Table 1}

Measurement of Tax Rate

\section{Items}

1. A fair sales tax rate should be the same for every type of business size.

2. A fair sales tax rate should be the same for every type of goods.

3. A fair sales tax rate should be the same for every type of sector.

Source: Adapted from Christensen et al. (1994)

Table 2

Measurement of Sales Tax Compliance

Items

1. Most business owner-managers always correctly record the details of a sale on the sale tax invoice.

2. Most business owner-managers generally believe that it is unacceptable to alter a sales tax invoice to allow a customer to claim more sales tax.

3. There are no circumstances when it might be acceptable to alter the details on a tax invoice to allow another business owner-managers to claim more sales tax.

4. If the customer's requests a tax invoice to be altered so they can claim more sales tax, business owner-managers will not do it for them.

5. If business owner-managers altered a tax invoice to allow a customer to claim more sales tax, they would not feel good about it.

6. There are no circumstances when business owner-managers find it justifiable to ask another sales tax registered business to alter a tax invoice so that they can claim more sales tax.

7. Most business owner-managers believe that it is unacceptable to alter a tax invoice to include private expenses as business expenses for sales tax purposes.

8. I think it is unacceptable to alter a tax invoice so that private expenses appear to be business-related in order for me to make a sales tax claim.

9. Some businesses owner-managers believe that its unacceptable to create fake invoices or alter invoices in order to claim sales tax refunds they are not entitled to.

10. I do not find faking invoice or altering an invoice justifying a sales tax refund.

11. If I created or in any way altered a tax invoice to get a claim for sales tax I was not entitled to, I would not feel good about it.

Source: Adapted from Woodward and Tan (2015).

Sales tax compliance is defined in this study as the correct record of details on sales tax invoice that is devoid of any fraudulent detail that could lead to the payment of less sales tax, and it is considered as the dependent variable. Studies that measured tax compliance found it too challenging to measure (e.g., Ahmed, Chetty, Mobarak, Rahman \& Singhal, 2012; Alm, 1999). According to Webly et al. (2004), sales tax compliance can be measured generally in broad terms, while Woodward and Tan (2015) stated that it can be referred to types of sales, either credit sales using tax invoices or cash sales transactions.

In the present study 11 items were adopted from Woodward and Tan (2015) to measure sales tax compliance, keeping into consideration that using tax invoice indicates that business becomes liable for sales tax if issued an invoice, which means, even if the business has not received the sale payment, they are liable to pay sales tax for it. This goes without saying that a tax invoice is the top significant document that is required by sales tax law for collecting sales tax when taxable goods/services are sold. The respondents' perceptions of sales tax compliance items were gauged using a 5-point Likert scale, ranging from 1 
(strongly disagree) to 5 (strongly agree), with number 1 indicating non-compliant of respondents towards sales tax payment, and number 5 indicating their compliance towards the same (refer to Table 2 for the sales tax compliance items).

\section{Research Method}

This study adopted a quantitative approach to accommodate the determination of the research questions. The study sample consisted of Jordanian-listed firms, which are generally divided into three by the ASE namely, the financial sector, the industrial sector and the service sector (Alshirah, Rahman, \& Mustapa, 2020). The last two latter sectors were covered in the study constituting 56 and 135 firms respectively in the year 2019. Seventy-one (71) questionnaires were retrieved from the respondents in a span of two months, from which 2 were found to be incomplete and were dropped from the analysis. Therefore, the total usable number of questionnaires was 169. According to Sekaran and Bougie (2016) and Lutfi (2020), the rate of response of $30 \%$ and above is an acceptable rate for a survey study.

Added to the above, Hair et al. (2010) set the 5:1 ratio for the number of observations to the number of latent study variables and since the present study has one latent construct, the number of usable responses numbered 169, this is an acceptable ratio. Also, other researchers explained that in minimum sample determination, the power level desired, level of significance and the number of predictors have to be kept under consideration (i.e., Green, 1991; Tabachnick \& Fidell, 2007). They proposed the following formula for calculating the required size $(\mathrm{N} \geq[50+8 \mathrm{~m}])$, where $\mathrm{m}$ depicts the number of independent latent variables and $\mathrm{n}$ depicts the number of cases. Using the above formula, the study's minimum required number of cases is 58 , which is lower than the number of cases gathered (169 cases) and thus, the number of observations was suitable to proceed to the next analysis stage.

\subsection{Data Analysis}

The PLS-SEM was adopted by this study for data analysis and hypotheses testing. Generally, scholars are unanimous in their description of PLS-SEM as an efficient system in specific conditions (Hair et al., 2016; Hair et al., 2012), and as a convenient tool used for analysis, particularly when the model encapsulates higher-order latent variables (Becker et al., 2012; Hair et al., 2011). It has also been evidenced to competently work in cases where each latent variable has several observed variables, making it a good alternative option to use when the data characteristics fail short of satisfying the regression assumptions of normality and sample size (Hair et al., 2011). Based on Hair et al.'s (2011) rule of thumb, the present study examined the measurement model's validity and reliability. Table 1 contains the values of Composite Reliability (CR) and Cronbach's Alpha (CA), which exceed the value of 0.70 , confirming the internal consistency and reliability of the variables. With regards to the indicator reliability, studies in literature (Hair et al., 2017; Hair et al., 2014) suggested 0.40 as the cut-off point. Moreover, the Average Variance Extracted (AVE) was also obtained to confirm the measurement model validity and the values of AVE are presented in Table 3 (all above the 0.50 threshold).

Table 3

Composite reliability, Cronbach's alpha, AVE and item loadings

\begin{tabular}{llllll}
\hline Latent construct & Items & Loading & CR & CA & AVE \\
\hline & STCM1 & 0.809 & & & \\
& STCM2 & 0.809 & & & \\
& STCM3 & 0.748 & 0.878 & 0.843 & \\
Sales tax compliance (STCM) & STCM4 & 0.671 & & \\
& STCM5 & 0.649 & & 0.514 \\
& STCM8 & 0.668 & & 0.817 \\
& STCM9 & 0.669 & & \\
\hline \multirow{2}{*}{ Tax Rate (TR) } & TR1 & 0.798 & 0.854 & \\
& TR2 & 0.824 & & \\
\hline
\end{tabular}

It is clear from Table 3 that the AVE of some of the items varied from 0.40 to 0.70 , necessitating their omission based on Hair et al.'s (2014) suggestion to increase the AVE values of the related latent variables to reach the least acceptable value. Items STCM6, STCM7, STCM10, and STCM11 were dropped. All the model's variables ended up explaining over half of their own indicator's variance, which confirms the presence of sufficient convergent validity. Also, for discriminant validity, AVE square root was examined (refer to Table 4), and the square root value of AVE for each variable exceeded its correlation with other variables. Thus, the measurement model was deemed to be valid and reliable, making it suitable for further analysis.

\section{Table 4}

The AVEs Square roots

\begin{tabular}{lcc}
\hline & STCM & TR \\
\hline STCM & 0.723 & \\
\hline
\end{tabular}


Following the analysis of the measurement model, the next step involved the testing and examination of the structural model for hypotheses testing. The path coefficients and the level of significance of each variable in the structural model were assessed with the help of PLS algorithm and bootstrapping procedures using a resample of 5000. Table 5 presents the findings of the structural model assessment. From the table, it is clear that tax rate-sales tax compliance has insignificant relationship $(\beta=$ $0.071, t=1.278, p>0.201)$, rejecting the proposed hypothesis. However, the study model managed to explain $27 \%\left(\mathrm{R}^{2}\right)$ of the sales tax compliance (dependent variable), which is evidence of its large exploratory power.

\section{Table 5}

The results of hypotheses testing (Direct relationship)

\begin{tabular}{llllcl}
\hline $\mathrm{H}$ & Relationship & Path coefficient & T -Value & P - Value & Decision \\
\hline H1 & TR $\rightarrow$ STCM & 0.071 & 1.278 & 0.201 & Not Supported \\
\hline
\end{tabular}

\section{Discussions}

The study primarily set out to determine the effect of tax rate on sales tax compliance as according to literature (Chau \& Leung, 2009; Richardson, 2006), tax rate is one of the major determinants of tax compliance. The study formulated the hypothesis that tax rate-sales tax compliance relationship would be negative and significant (H1). However, the empirical findings rejected the influence of tax rate on sales tax compliance, and essentially rejected the hypothesis. This finding is against the prediction of the deterrence theory (Allingham \& Sandmo, 1972), whereby tax rate significantly influences tax compliance. Literature dedicated to sales tax compliance has largely ignored its relationship with tax rate, but what few studies there are supported a significant relationship and these include, Giesecke and Tran (2012), Batten and Matthews (2003). The contrasting result found in the present study can be related to its reliance on behavioral perception of firms when it comes to credit sales on tax invoice issuance.

Furthermore, majority of the studies in literature concerning income tax revealed a significant relationship between income tax compliance and tax rate (see Inasius, 2015; Hauptman et al., 2014; Mukhlis et al., 2014; Kuehn, 2014; Pellizzari \& Rizzi, 2014; Barbuta-Misu, 2011), while some other studies reported the relationship to be insignificant (e.g., Modugu et al., 2012; Richardson, 2006). In addition to the above studies, other authors found tax rates to have an ambiguous effect on tax evasion, arguing that decreasing rates of taxes do not always lead to decreased occurrences of tax evasion (Allingham \& Sandmo, 1972). On the whole, this study found the tax rate to have an insignificant relationship with the sales tax compliance among Jordanian companies.

\section{Conclusion, Policy Implications, Limitations and Recommendations}

On the basis of the achieved objective of the study, several significant contributions to theory and practice can be discerned, in the context of companies in Jordan. First, the study contributes to theory dedicated to accounting literature, particularly to the relationship between sales tax compliance and tax rate in Jordan, and other developing nations. Very few studies have been conducted in this context, with existing studies focusing on New Zealand and Bangladesh (Woodward \& Tan, 2015; Faridy et al., 2014), leaving the Middle East and Arab countries lagging behind. To the best of the author's knowledge, this is the first study to be carried out to examine sales tax compliance in a Middle East nation and in Jordan specifically, as a result of which, the study minimizes the related gap in literature. The study findings evidenced that tax rates do significantly influence sales tax compliance, in that it either decreases or increases the latter. When it comes to resolving the tax rate issue, it is the belief of firms in general that they are not paying sales tax but instead collecting sales tax from the customers as agents.

Like other studies of its caliber, this study has its own limitations that should be taken into account when generalizing and interpreting the results. Such limitations also pave the way for opportunities that future studies can avail from. From the findings, it is evident that the model explained $24 \%$ of the total variance in sales tax compliance, indicating the role of other variables in explaining the remaining $76 \%$ of the variance. Hence, in future studies, other additional constructs can be included to examine their influence of sales tax compliance like tax knowledge, religion, external audit, tax auditor gender, and tax service quality. This study can be the stepping stone to extensive research in sales tax compliance in the Arab world, particularly in the Middle East, as it focuses on a Middle Eastern country, Jordan. In this regard, future studies can make use of the theoretical framework keeping in mind the geographical region it is confined to. Furthermore, future studies can extend the study model to examine other countries in the Middle Eastern region.

\section{References}

Abdul-Jabbar, H. (2009). Income tax non-compliance of small and medium enterprises in Malaysia: Determinants and tax compliance costs (Doctoral dissertation, Curtin University). 
Abdul-Jabbar, H., \& Pope, J. (2008). Exploring the relationship between tax compliance costs and compliance issues in Malaysia. Journal of Applied Law and Policy, 1(1), 1-20.

Adams, C., \& Webley, P. (2001). Small business owners attitudes on VAT compliance in the UK. Journal of Economic Psychology, 22(1), 195-216.

Allingham, M. G., \& Sandmo, A. (1972). Income tax evasion: A theoretical analysis. Journal of Public Economics, 1(3-4), 323338.

Alm, J. (2019). What Motivates Tax Compliance?. Journal of Economic Surveys, 33(2), 353-388.

Alm, J. (1991). A perspective on the experimental analysis of taxpayer reporting. The Accounting Review, 66(3), 577-593.

Alm, J., Bahi, R., \& Murray, M. N. (1990). Tax structure and tax compliance. Review of Economics \& Statistics, 72(4), 603613.

Alm, J., Jackson, B. R., \& McKee, M. (1993). Fiscal exchange, collective decision institutions, and tax compliance. Journal of Economic Behavior \& Organization, 22(3), 285-303.

Alm, J., McClelland, G. H., \& Schulze, W. D. (1992). Why do people pay taxes? Journal of Public Economics, 48(1), $21-38$.

Alm, J., \& Torgler, B. (2011). Do ethics matter? tax compliance and morality. Journal of Business Ethics, $101(4), 635-651$.

Alshir'ah, A. F., Abdul-Jabbar, H., \& Samsudin, R. S. (2016). Determinants of sales tax compliance in small and medium enterprises in Jordan : A call for empirical research. World Journal of Management and Behavioral Studies, 4(1), 41-46.

Alshira'h, A. F., Abdul-Jabbar, H., \& Samsudin, R. S. (2018). Sales tax compliance model for the Jordanian small and medium enterprises research. Journal of Advanced Research in Social and Behavioural Sciences, 10(2), 115-130.

Alshira'h, A. F., \& Abdul-Jabbar, H. (2019a). The effect of tax fairness on sales tax compliance among Jordanian manufacturing SMEs. Academy of Accounting and Financial Studies Journal, 23(2), 1-11.

Alshira'h, A. F. (2019). The effect of peer influence on sales tax compliance among Jordanian SMEs. International Journal of Academic Research in Business and Social Sciences, 9(3), 710-721

Alshira'h, A. F. A. (2018). Determinants of sales tax compliance among Jordanian SMEs: the moderating effect of public governance (Unpublished Doctoral dissertation, Universiti Utara Malaysia).

Alshira'h, A. F., Abdul-Jabbar, H., \& Samsudin, R. S. (2019). The effect of tax moral on sales tax compliance among Jordanian SMEs. International Journal of Academic Research in Accounting, Finance and Management Sciences, 9(1), 30-41.

Alshira'h, A. F., AL-Shatnawi, H. M., Alsqour, M. K., Alshirah, M. H. (2020). The Influence of Tax Complexity on Sales Tax Compliance among Jordanian SMEs. International Journal of Academic Research in Accounting, Finance and Management Sciences, 10 (1), 250-260

Alshira'h, A. F., \& Abdul-Jabbar, H. (2019b). A conceptual model of sales tax compliance among Jordanian SMEs and its implications for future research. International Journal of Economics and Finance, 11(5), 114-114.

Alshira'h, A. F., \& Abdul-Jabbar, H. (2020). Moderating role of patriotism on sales tax compliance among Jordanian SMEs. International Journal of Islamic and Middle Eastern Finance and Management 13(3), 389-415Arachi, G., \& Santoro, A. (2007). Tax enforcement for SMEs : lessons from the Italian experience? eJournal of Tax Research, 5(2), $225-243$.

Alshira'h, A.F., Al-Shatnawi, H.M., Al-Okaily, M., Lutfi, A. and Alshirah, M.H. (2020). Do public governance and patriotism matter? Sales tax compliance among small and medium enterprises in developing countries: Jordanian evidence", EuroMed Journal of Business, Vol. ahead-of-print No. ahead-of-print

Alshirah, M. H., Rahman, A. A., \& Mustapa, I. R. (2020). Board of directors' characteristics and corporate risk disclosure: the moderating role of family ownership. EuroMed Journal of Business, 15(2), 219-252.

Barbuta-Misu, N. (2011). A review of factors for tax compliance.

Batten, D., \& Matthews, S. (2003). Direct Use of Tax Data for the Annual Survey of Manufactures. Variable Selection Study, Internal Statistics Canada Document.

Bird, R. M., \& Martinez-Vazquez, J. (2008). Tax effort in developing countries and high income countries: The impact of corruption, voice and accountability. Economic Analysis and Policy, 38(1), 55-71.

Birškytè, L. (2014). The impact of trust in government on tax paying behavior of nonfarm sole proprietors. Analele Ştiinţifice ale Universităţii» Alexandru Ioan Cuza «din Iaşi. Ştiinţe economice, 61(1), 1-15.

Brown, R., \& Mazur, M. (2003). IRS â€ $€^{\mathrm{TM}}$ s comprehensive approach to compliance measurement. National Tax Journal, 56(3), 689-700.

Bruce-Twum, E. (2014). Gift tax compliance in Ghana, an empirical study. Journal of Finance and Accounting, $2(1), 1-7$.

Chau, G., \& Leung, P. (2009). A critical review of Fischer's tax compliance model: A research systhesis. International Accounting, Auditing and Taxation, 1(2), 34-40.

Christensen, A.L., Weihrich, S.G. \& Gerbing, M.D. (1994). The impact of education on perceptions of tax fairness. Advances in Taxation, 6, 63-94.

Das-Gupta, A., \& Gang, I. (2003). Value added tax evasion, auditing and transactions matching. Inl. Maclarn(2003) Institutional elements of tax design and reform. The World Bank, Washington, USA.

Devos, K. (2005). The attitudes of tertiary students on tax evasian. eJournal of Tax Research, 3(2), $222-273$.

Faridy, N., Freudenberg, B., Sarker, T., \& Copp, R. (2016). The hidden compliance cost of VAT: An exploration of 
psychological and corruption costs of VAT in a developing country. eJournal of Tax Research, 14(1), 166-205.

Feld, L. P., \& Frey, B. (2007). Tax compliance as the result of a psychological tax contract: The role of incentives and responsive regulation. Law and Policy, 29(1), 102-120.

Giesecke, J., \& Tran, N. H. (2012). A general framework for measuring VAT compliance rates. Applied Economics, 44(15), 1867-1889.

Green, S. B. (1991). How many subjects does it take to do a regression analysis? Multivariate Behavioral Research, 26(3), 499510.

Gundarapu, S., \& Vadde, S. (2012). Factors That Influence Rental Tax Payers' Compliance With Tax System: an Empirical Study Of Mekelle City, Ethiopia. Researchers World-International Refereed Research Journal of Arts. Science \& Commerce, 3(2).

Hair, J. F., Sarstedt, M., Ringle, C. M., \& Mena, J. A. (2012). An assessment of the use of partial least squares structural equation modeling in marketing research. Journal of the Academy of Marketing Science, 40, 414-433.

Hair, J. F., Sarstedt, M., Hopkins, L., \& Kuppelwieser, V. G. (2014). Partial least squares structural equation modeling (PLSSEM): An emerging tool in business research. European Business Review, 26(2), 106-121.

Hair, J. F., Hult, G. T. M., Ringle, C., \& Sarstedt, M. (2016). A primer on partial least squares structural equation modeling (PLS-SEM). Sage Publications.

Hair, J. F., Ringle, C. M., \& Sarstedt, M. (2011). PLS-SEM: Indeed a Silver Bullet. Journal of Marketing Theory and Practice, $19(2), 139-151$.

Hair Jr, J. F., Sarstedt, M., Ringle, C. M., \& Gudergan, S. P. (2017). Advanced issues in partial least squares structural equation modeling. Sage Publications

Hair, J. F., Black, W. C., Babin, B. J., \& Anderson, R. E. (2010). Multivariate Data Analysis (7th Ed). Upper Saddle River, NJ: Prentice Hall.

Hauptman, L., Horvat, M., \& Korez-Vide, R. (2014). Improving tax administration's services as a factor of tax compliance: The case of tax audit. Lex localis, 12(3), 481-501.

Inasius, F. (2019). Factors influencing SME tax compliance: Evidence from Indonesia. International Journal of Public Administration, 42(5), 367-379.

Jackson, B. R., \& Milliron, V. C. (1986). Tax compliance research: Findings, problems, and prospects. Journal of accounting literature, 5(1), 125-165.

JESC. (2014). Tax evasion in Jordan: causes, ways.www.esc.jo.

Kasipillai, J., \& Abdul-Jabbar, H. (2006). Gender and ethnicity differences in tax compliance. Asian Academy of Management Journal, 11(2), 73-88.

Kasipillai, J., Aripin, N., \& Amran, N. A. (2003). The influence of education on tax avoidance and tax evasion. eJournal of Tax Research, 1(2), 134-146.

Kirchler, E., Kogler, C., \& Muehlbacher, S. (2014). Cooperative tax compliance: From deterrence to deference. Current Directions in Psychological Science, 23(2), 87-92.

Kirchler, E., Niemirowski, A., \& Wearing, A. (2006). Shared subjective views, intent to cooperate and tax compliance: Similarities between Australian taxpayers and tax officers. Journal of Economic Psychology, 27(4), 502-517.

Kirchler, E., \& Wahl, I. (2010). Tax compliance inventory TAX-I: Designing an inventory for surveys of tax compliance. Journal of Economic Psychology, 31(3), 331-346.

Kuehn, Z. (2014). Tax rates, governance, and the informal economy in high-income countries. Economic Inquiry, 52(1), 405430.

Likhovski, A. (2007). Training in citizenship: Tax compliance and modernity. Law \& Social Inquiry, 32(3), 665-700.

Lutfi, A. (2020). Investigating the Moderating Role of Environmental Uncertainty between Institutional Pressures and ERP Adoption in Jordanian SMEs. Journal of Open Innovation: Technology, Market, and Complexity, 6(3), 91.

Marandu, E. E., Mbekomize, C. J., \& Ifezue, A. N. (2015). Determinants of tax compliance: A review of factors and conceptualizations. International Journal of Economics and Finance, 7(9), 207-218.

Mascagni, G., Moore, M., \& Mccluskey, R. (2014). Tax revenue mobilisation in developing countries: Issues and challenges(Working Paper). Eruopean Parliment, Directorate-General for External Policies of the Union.

McKerchar, M., \& Evans, C. (2009). Sustaining growth in developing economies through improved taxpayer compliance: challenges for policy makers and revenue authorities. eJournal of Tax Research, 7(2), 171-201.

Modugu, P. K., Eragbhe, E., \& Izedonmi, F. (2012). Government accountability and voluntary tax compliance in Nigeria. Research Journal of Finance and Accounting, 3(5), 69-76.

Mukhlis, I., Utomo, S. H., \& Soesetyo, Y. (2014). Increasing tax compliance through strengthening capacity of education sector for export oriented SMEs handicraft field in East Java Indonesia. European Scientific Journal, 10(7).

Palil, M. R., \& Mustapha, A. F. (2011). Factors affecting tax compliance behaviour in self assessment system. African Journal of Business Management, 5(33), 12864-12872.

Pellizzari, P., \& Rizzi, D. (2014). Citizenship and power in an agent-based model of tax compliance with public expenditure. Journal of Economic Psychology, 40, 35-48. 
Pope, J., \& Abdul-Jabbar, H. (2008). Small and medium-sized enterprises and tax compliance burden in Malaysia: Issues and challenges for tax administration. Small Enterprise Research, 16(1), 47-60.

Richardson, G. (2006). Determinants of tax evasion: A cross-country investigation. Journal of international Accounting, Auditing and taxation, 15(2), 150-169.

Ritsatos, T. (2014). Tax evasion and compliance: from the neo classical paradigm to behavioural economics, a review. Journal of Accounting \& Organizational Change, 10(2), 244-262.

Sekaran, U., \& Bougie, R. (2016). Research Methods For Business (Fifth Edit). John Wiley \& Sons, Inc. New York, NY, USA.

Sawyer, A. (2014). Comparing the Swiss and United Kingdom cooperation agreements with their respective agreements under the Foreign account tax compliance Act. eJournal of Tax Research, 12(2), 285-318.

Seidu, A. N., Abdul, I. W., \& Sebil, C. (2015). Modelling the causes of tax default among small and medium scale enterprises (SMEs) In the Tamale Metropolis of Ghana. European Scientific Journal, 11(1).

Shamsudin, S. M. (2012). Corporate governance and tax compliance: a study of SMEs in Malaysia (Doctoral dissertation, Universiti Teknologi MARA).

Slemrod, J. (2004). The economics of corporate tax selfishness. National Tax Journal, 57(4), 877-899.

Slemrod, J., Yitzhaki, S., 2002. Tax avoidance, evasion, and administration. In: Auerbach, A., Feldstein, M. (Eds.), Handbook of Public Economics,vol. 3.Elsevier Science, Amsterdam, pp. 1423-1470.

Strader, J., \& Fogliasso, C. (1989). An investigation of some factors affecting taxpayer non-compliance. Accounting \& Business Research, 20(77), 39-46.

Swistak, A. (2015). Tax penalties in SME tax compliance. Flinancial Theory and Practice, 40(1), $129-147$.

Tabachnick, B. G., \& Fidell, L. S. (2007). Using Multivariate Statistics (5th Ed.). Boston: Pearson Education Inc.

Tehulu, T. A., \& Dinberu, Y. D. (2014). Determinants of tax compliance behavior in Ethiopia: The case of Bahir Dar city taxpayers. Journal of Economics and Sustainable Development, 5(15), 268-280.

Torgler, B. (2003a). Tax morale, rule-governed behaviour and trust. Constitutional Political Economy, 14(2), 119-140.

Torgler, B. (2003b). To evade taxes or not to evade: that is the question. The Journal of Socio-Economics, 32(3), $283-302$.

Torgler, B., \& Schaltegger, C. A. (2005). Tax morale and fiscal policy (Unpublished Working Paper No. 1748). Center for Research in Economics, Management and the Arts.

Vogel, J. (1974). Taxation and public opinion in Sweden: An interpretation of recent survey data. National Tax Journal, 27(4), 499-513.

Weber, T. O., Fooken, J., \& Herrmann, B. (2014). Behavioural economics and taxation. European Commission Taxation Papers.

Woodward, L., \& Tan, L. M. (2015). Small business owners' attitudes toward GST compliance: a preliminary study. Austl. Tax F., 30, 517.

Young Entrepreneure Association. (2011). Small and medium business agenda. Http://www.cipe-Arabia.org/. 
(C) 2021 by the authors; licensee Growing Science, Canada. This is an open access article distributed under the terms and conditions of the Creative Commons Attribution (CC-BY) license (http://creativecommons.org/licenses/by/4.0/). 